\title{
The Implementation of Basic Guidance Services in Selected Diocesan Catholic Schools in the Province of Antique
}

\author{
Genalyn E. Gipalen ${ }^{1}$ and Dennis V. Madrigal² \\ ${ }^{1}$ Dao Catholic High School, Inc., Antique, Philippines \\ ${ }^{2}$ University of Negros Occidental-Recoletos, Bacolod City, Philippines
}

\begin{abstract}
Article history
Submitted: 24 October 2020

Revised: 11 November 2020

Accepted: 12 November 2020

\section{Keywords}

Guidance and Counseling

Basic Guidance Services

Implementation

Challenges

Diocesan Catholic Schools

Descriptive-Comparative

Antique
\end{abstract}

Introduction. Guidance and counseling is a crucial concern today to aid the educational, vocational, and psychological potentials of the students for optimum achievement and adequate adjustment in the varied life situations. The primary purpose of a school's guidance and counseling program is to provide a broad spectrum of services to students, such as student assessment, the information service, placement and follow-up, and counseling assistance. Hence, this study intended to determine the extent of implementation of guidance services in Catholic schools in selected Diocesan Catholic Schools in Antique during the Academic Year 2019-2020. Likewise, it identified the challenges encountered by school personnel and students in implementing school guidance services. The study's findings were used as a baseline to develop a proposed program for the enhancement of the implementation of basic guidance services in Diocesan Catholic schools.

Methods. A descriptive-comparative research design was used to describe the extent and challenges encountered in implementing basic guidance services of selected Diocesan Catholic schools in the province of Antique for the academic year 2019-2020. Using the total enumeration, 52 school personnel and teachers participated, and using stratified random sampling, 678 students participated in the study. There were 683 school personnel and high school students who participated in the study. The data was gathered using a validated and reliability tested researcher-made instrument. Mean, Standard Deviation, frequency count, percentage distribution, Kruskal-Wallis and Mann Whitney U test were used data analysis.

Results. The findings of the study revealed that the extent of implementation of guidance services in selected Catholic schools is of great extent, which means that the schools have substantially implemented the guidance services of the school with placement, and follow-up as the highest and lowest, respectively. When assessors are grouped according to school origin and designation, the implementation of guidance services was rated to a great extent. Both students and school personnel considered placement and follow-up as strong and weak services, respectively. Moreover, the findings showed that there was a significant difference in the extent of basic guidance services when assessors are grouped according to the designation and the school of origin on how they viewed the implementation of the guidance services, namely: information services, individual inventory services, counseling services, placement services, and follow-up services. Furthermore, the results revealed that the topmost challenges in the implementation of guidance services were inadequate facilities, lack of awareness on guidance services among students, basic facilitating skills for teachers, inadequate time to render guidance services, and inadequate resources for guidance program. The findings of the study indicate that rendering guidance services has not been easy.

Conclusion. The school program on guidance and counseling services is essential in helping the educational, vocational, and psychological potentials of the students to their varied preferences. School heads and the teachers have a huge responsibility to support the guidance designate to implement the guidance and counseling program for students' holistic development. However, there are areas for improvement in the guidance services of Catholic schools so that students can avail adequate guidance and help in developing their educational, vocational, and psychological potentials. Hence, it challenges Catholic schools to invest more in training guidance counselors, 
improving facilities, and providing resources vital to fostering and effectively implementing school's guidance services. As catholic institutions committed to providing a quality Catholic Education, guidance and counseling services are essential for student support services, which concern the holistic development of the students and school personnel.

Practical Value of the Paper. The study significantly contributes to the few existing literature on the implementation of basic guidance services when grouped according to school origin and designation of assessors, and challenges encountered by the school personnel and students. In addition, the findings of the study were used as a baseline to develop a proposed program for the enhancement of the implementation of basic guidance services.

\section{References}

Asamari, A. A. (2018). Evaluation of the Implementation of Selected Guidance Services in Senior High Schools in The Sagnarigu Municipality-Ghana. UDS International Journal of Development, 5(2), 72-81.

Cooley, L. (Ed.). (2009). The Power of Groups: Solution-focused Group Counseling in Schools. Corwin Press.

Eyo, M., Joshua, A., \& Esuong, A. (2010). The attitude of secondary school students towards guidance and counseling services in Cross River State. Edo Journal of Counselling, 3(1), 87-99.

Hossain, S., \& Rajib, A.F. (2013). Guidance and counseling services in schools of Bangladesh: An Exploratory Study. International Journal of Science and Research (ISR), 2 (10, 132-138.

Idowu, A. I. (2004). Guidance and counseling: An overview. In A. I. Idowu (Ed). Guidance and counseling in education. Ilorin: Indemac.

Kemetse, G., Nyarko-Sampson, E., Nkyi, A., \& Nyarko, P. (2018). Implementation of Guidance Services in Senior High Schools in Ho Municipality, Ghana. European Journal of Education Studies, 0.

Lunenburg, F. C. (2010). School guidance and counseling services. Schooling, 1(1), 1-9.

Mbongo, E., Maöwes, A, \& Chata, C. (2016). Factors Impacting the Implementation of Guidance and Counselling Services in Secondary Schools in the Ohangwena Region of Namibia. International Jornal for Innovation Education and Research, 4(5).

Nyamwaka, E. O., Ondima, P.C., Nyamwange, C., Ombaba, S.A.M.S.O.N., \& Magaki, E.K. (2013). Assessment of Implementation levels of Guidance and Counseling Program in Kenyan Secondary Schools: A case of Sotik district, Bomet County, Kenya. Journal of Education Practice, 4(3), 178-186.

Tuason, M. T. G., Galang Fernandez, K. T., Catipon, M. A. D., Trivino-Dey, L., \& Arellano-Carandang, M. L. (2012). Counseling in the Philippines: Past, present, and future. Journal of Counseling \& Development, 90(3), 373-377.

\section{Correspondence:}

Genalyn E. Gipalen [genalyngipalen0822@gmail.com]

http://orcid.org/0000-0001-6010-8863 